\title{
Variation in the Site of Lithiation of 2-(2-Methylphenyl)ethanamine Derivatives
}

Keith Smith,* Gamal A. El-Hiti* ${ }^{*}$ and Mohammed B. Alshammari

School of Chemistry, Cardiff University, Main Building, Park Place, Cardiff CF10 3AT, U.K; Fax: +44(2920)870600; Tel: +44(2920)870600; E-mail: smithk13@cardiff.ac.uk and elhitiga@cardiff.ac.uk

† Permanent address: Department of Chemistry, Faculty of Science, Tanta University, Tanta 31527, Egypt. 


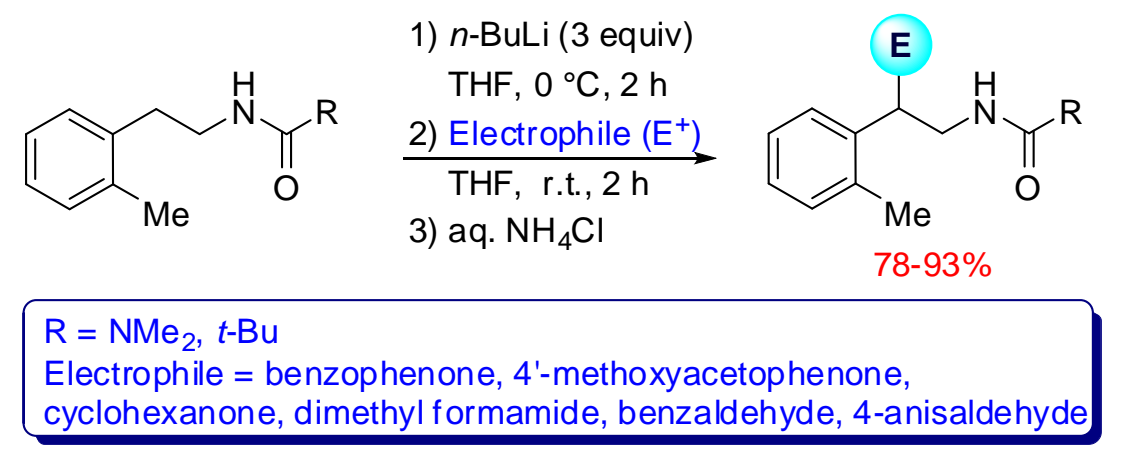

\begin{abstract}
Unexpectedly, lithiation of $N^{\prime}$-(2-(2-methylphenyl)ethyl)- $N, N$-dimethylurea with three equivalents of $n$-butyllithium in anhydrous THF at $0{ }^{\circ} \mathrm{C}$ takes place on the nitrogen and on the $\mathrm{CH}_{2}$ next to the 2-methylphenyl ring ( $\alpha$-lithiation). The lithium reagent thus obtained reacts with various electrophiles to give the corresponding substituted derivatives in excellent yields. Similarly, lithiation of $N$-(2-(2-methylphenyl)ethyl)pivalamide under similar reaction conditions followed by reaction with benzophenone as a representative electrophile gave the corresponding $\alpha$-substituted product in high yield. Surprisingly, no products resulting from lateral lithiation were observed under the conditions tried, which sharply contrasts with the reported results for lateral lithiation of tert-butyl (2-(2-methylphenyl)ethyl)carbamate.
\end{abstract}

Keywords: lateral lithiation, side-chain lithiation, $N^{\prime}$-(2-(2-methylphenyl)ethyl)- $N, N$ dimethylurea, $N$-(2-(2-methylphenyl)ethyl)pivalamide, electrophile, synthesis

\title{
INTRODUCTION
}

Phenylethylamines represent an important class of chemicals encompassing a whole range of biologically active compounds. They are therefore significant for both industry and academe and methods for their synthesis are of considerable interest. Organolithium reagents produced in-situ in lithiation reactions play a reliable and efficient role in functionalizing a broad-range of aromatic and/or heterocyclic systems regioselectively. ${ }^{1-4}$ Lateral (benzylic) lithiation of alkyl groups that are ortho- to a directing metalating group (DMG) is a wellknown example of such methodology in organic synthesis. ${ }^{1 \mathrm{a}, 5}$ Such lateral lithiation of benzenoid systems is encouraged by a stabilizing group capable of delocalizing a negative 
charge, stabilizing the organolithium by coordination, or acidifying the benzylic proton by an electron-withdrawing inductive effect. ${ }^{1 \mathrm{a}, 5}$

In the course of our own studies of lithiation reactions we have developed several simple and efficient lithiation procedures for preparation of various substituted aromatics and heteroaromatics. ${ }^{6}$ For example, we have successfully lithiated and substituted various $N^{\prime}$-phenyl- $N, N$-dimethylureas, $N$-(substituted benzyl)pivalamides and $N^{\prime}$-(substituted benzyl)$N$ - $N$-dimethylureas regioselectively using $n$-butyllithium or $t$-butyllithium in anhydrous tetrahydrofuran. ${ }^{7-9}$ Such processes have been applied for the production of various substituted heterocycles. ${ }^{10-12}$ As part of such studies, we have recently shown that lithiation of $N^{\prime}$-phenethyl- $N, N$-dimethylurea and $N^{\prime}$-(3-phenylpropyl)- $N, N$-dimethylurea, at -78 and $0{ }^{\circ} \mathrm{C}$, respectively, with three equivalents of $t$-BuLi in anhydrous THF takes place on the nitrogen and on the $\mathrm{CH}_{2}$ next to the phenyl ring ( $\alpha$-lithiation). ${ }^{13}$ On the other hand, lithiation of $N^{\prime}$-(4-phenylbutyl)- $N, N$-dimethylurea, where the coordinating group is further away from the $\alpha-\mathrm{CH}_{2}$ position, takes place on one of the methyl groups of the urea unit with $t$-BuLi at $0{ }^{\circ} \mathrm{C} .{ }^{13}$ We wished to see whether there were similar effects of chain length on lateral lithiation of $\omega$-(2-methylphenyl)alkyl derivatives. Recently, we have shown that lateral lithiation of 2-methylbenzyl derivatives 1 with $t$-BuLi at $-78{ }^{\circ} \mathrm{C}$ followed by reactions with various electrophiles was successful to produce the corresponding substituted derivatives 2 in high yields (Scheme 1). ${ }^{9}$ We have now turned our attention to investigation of lithiation of 2-(2-methylphenyl)ethyl derivatives.

\section{Scheme 1. Lateral lithiation and substitution of 2-methylbenzylamines (1)}

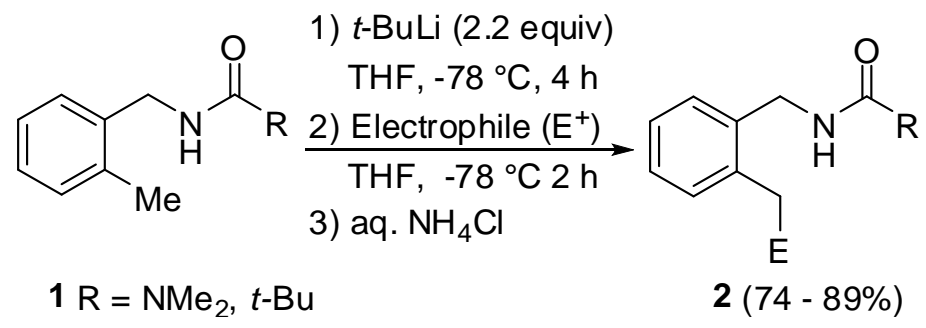

Lateral lithiation of tert-butyl 2-(2-methylphenyl)ethylcarbamate with $t$-BuLi (2.4 equiv.) at $-60{ }^{\circ} \mathrm{C}$ has been reported by Clark. ${ }^{14}$ The lithium reagent obtained was allowed to react with iodomethane and carbon dioxide (in the presence of $\mathrm{CH}_{2} \mathrm{~N}_{2}$ ) as electrophiles at $c a$. -25 to $-30{ }^{\circ} \mathrm{C}$ to give the corresponding substituted products in 80 and $67 \%$ yields, respectively. ${ }^{14}$ However, there are no reports of lithiation and substitution of $N^{\prime}$-(2-(2- 
methylphenyl)ethyl)- $N, N$-dimethylurea and $N$-(2-(2-methylphenyl)ethyl)pivalamide. We now report that lithiation of these derivatives unexpectedly take place at the $\alpha-\mathrm{CH}_{2}$ position, rather than laterally on the methyl group.

\section{RESULTS AND DISCUSSION}

The first task was to synthesize $N^{\prime}$-(2-(2-methylphenyl)ethyl)- $N, N$-dimethylurea (4). Compound 4 was synthesized in $95 \%$ yield after crystallization, based on a literature procedure for analogous compounds, ${ }^{9,13}$ from reaction of 2-(2-methylphenyl)ethanamine (3) with dimethylcarbamoyl chloride (DMCC) in dichloromethane in the presence of triethylamine under reflux for $1 \mathrm{~h}$ (Scheme 2).

\section{Scheme 2. Synthesis of $N^{\prime}$-(2-(2-methylphenyl)ethyl)- $N, N$-dimethylurea (4)}

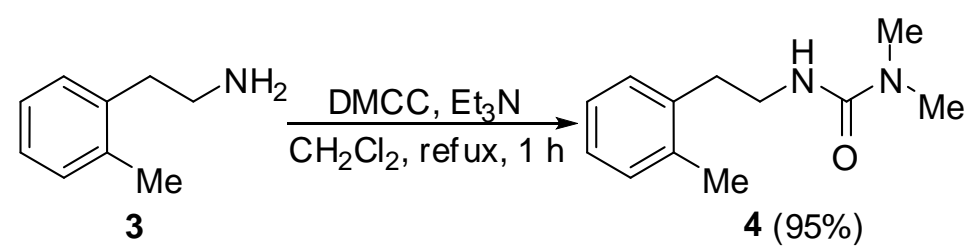

Initially the reaction of $\mathbf{4}$ with $n$-BuLi (2.2 equiv.) was carried out in anhydrous THF under a nitrogen atmosphere at $-78{ }^{\circ} \mathrm{C}$. Initial addition of $n$-BuLi provided a pale yellow solution, presumably because of formation of the monolithium reagent 5 (Scheme 3), until approximately one equivalent had been added, then gave a deep yellow solution as the remaining $n$-BuLi was added, presumably because of formation of a dilithium reagent. The mixture was stirred for $2 \mathrm{~h}$ at $-78{ }^{\circ} \mathrm{C}$. Benzophenone (1.2 equiv.) was added and the mixture was stirred for another $1 \mathrm{~h}$ at $-78{ }^{\circ} \mathrm{C}$ and then quenched by the addition of aqueous ammonium chloride solution. The starting material 4 was recovered in $80 \%$ yield, but a new compound, shown by its ${ }^{1} \mathrm{H}$ NMR spectrum (which exhibited diastereotopicity for the $\mathrm{CH}_{2}$ protons) to be 7 (Scheme 3), was produced in 12\% yield after purification by column chromatography (Table 1; entry 1). This implied that the intermediate dilithium reagent was 6 (Scheme 3) and not the expected laterally lithiated one.

Use of MeLi (1.1 equiv.) to remove the NH proton, followed by $n$-BuLi (1.1 equiv.) at $-78{ }^{\circ} \mathrm{C}$ under similar reaction conditions provided only a trace of 7 . The yield of 7 was improved but to only $30 \%$ when MeLi (1.1 equiv.) followed by $n$-BuLi (2.2 equiv.) were used at $-78{ }^{\circ} \mathrm{C}$ under similar reaction conditions. Raising the temperature of lithiation to $0{ }^{\circ} \mathrm{C}$ had a much greater effect on the yield of product, giving 7 in $65 \%$ yield after a lithiation period of 
just 30 minutes (Table 1; entry 2). On the other hand, use of $t$-BuLi or $s$-BuLi at $0{ }^{\circ} \mathrm{C}$ gave 7 in lower yields, 55 and 2\%, respectively, and no product was obtained when LDA was used as the lithium reagent. In none of the reactions was any product of lateral lithiation isolated. Therefore, use of $n$-BuLi at $0{ }^{\circ} \mathrm{C}$ was selected for further study and several experiments were conducted to try to improve the yield of $\mathbf{7}$ or to find conditions under which lateral lithiation could be achieved instead. The crude products were analyzed by ${ }^{1} \mathrm{H}$ NMR spectroscopy and the approximate yields of 7 obtained are summarized in Table 1.

Scheme 3. Lithiation of 4 followed by reaction with benzophenone

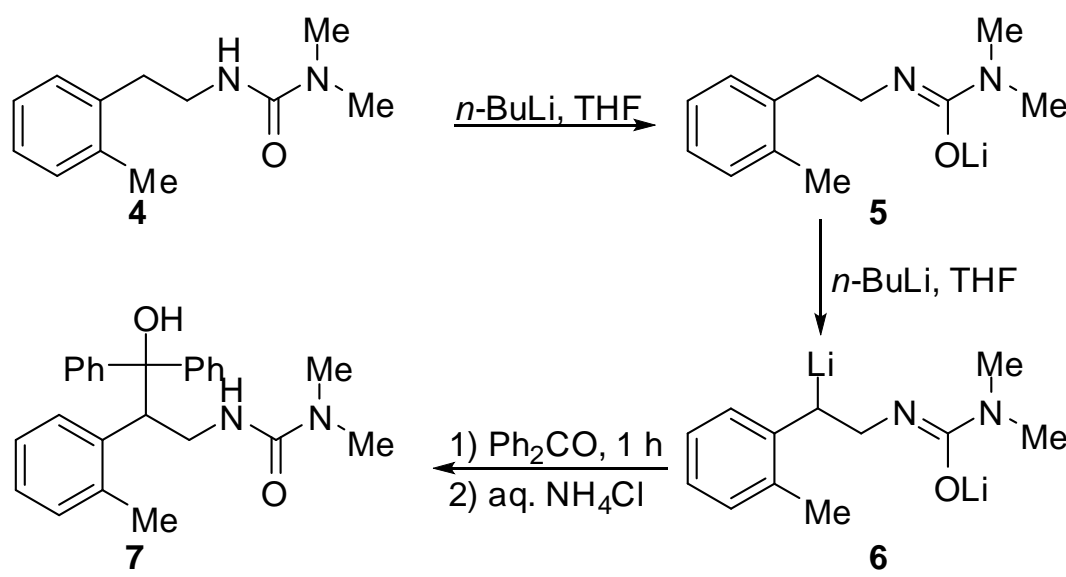

Table 1. Synthesis of 7 under Various Reaction Conditions According to Scheme 3

\begin{tabular}{|c|c|c|c|c|c|}
\hline \multirow[t]{2}{*}{ Entry } & \multicolumn{2}{|c|}{$n$-BuLi } & \multirow[t]{2}{*}{ Temp. $\left({ }^{\circ} \mathrm{C}\right)$} & \multirow{2}{*}{$\begin{array}{l}\mathrm{Ph}_{2} \mathrm{CO} \text { (mol } \\
\text { equiv.) }\end{array}$} & \multirow[t]{2}{*}{ Yield of $7(\%)^{a}$} \\
\hline & mol equiv. & $\mathrm{T}(\mathrm{h})$ & & & \\
\hline 1 & 2.2 & 2 & -78 & 1.2 & $12^{b}$ \\
\hline 2 & 2.2 & 0.5 & 0 & 1.2 & $65^{b, c}$ \\
\hline 3 & 2.2 & 0.5 & 0 & 2.2 & $69^{\mathrm{b}, \mathrm{c}}$ \\
\hline 4 & 2.2 & 1 & 0 & 2.2 & $78^{\mathrm{b}, \mathrm{c}}$ \\
\hline 5 & 2.2 & 2 & 0 & 1.2 & $76^{\mathrm{b}, \mathrm{c}}$ \\
\hline 6 & 2.2 & 2 & 0 & 2.2 & 83 \\
\hline 7 & 2.2 & 2 & 0 & 3.3 & 83 \\
\hline 8 & 3.0 & 0.5 & 0 & 1.2 & 80 \\
\hline 9 & 3.0 & 1 & 0 & 1.2 & 83 \\
\hline 10 & 3.0 & 2 & 0 & 1.2 & 93 \\
\hline
\end{tabular}

The results indicated that the highest yield of 7 was obtained by use of three equivalents of $n$-BuLi as the lithium reagent at $0{ }^{\circ} \mathrm{C}$ for $2 \mathrm{~h}$ (Table 1; Entry 10), giving 7 in 
93\% yield after purification by column chromatography, although a good yield (up to 83\%) could be achieved with just a small excess over the theoretical two equivalents of $n$-BuLi. Use of a larger quantity of $n$-BuLi probably simply increased the rate of lithiation, particularly in the later stages of the reaction, but clearly had practical advantage in terms of yield of desirable product. It was obvious that no lateral lithiation had taken place under the conditions tried and in all cases 7 was the only new product isolated. Clearly, $\alpha$-lithiation had taken place on the $\mathrm{CH}_{2}$ group rather than lateral lithiation on the methyl group at the 2-position, which was unexpected.

It was therefore interesting to see if reactions of the lithium intermediate $\mathbf{6}$ with other electrophiles would be useful, making the reaction more general. Consequently, reactions of 6, prepared in-situ from compound 4, with other electrophiles (4'-methoxyacetophenone, cyclohexanone, dimethyl formamide, benzaldehyde and 4-anisaldehyde) were carried out. Each reaction was conducted under identical conditions and then quenched by the addition of aq. $\mathrm{NH}_{4} \mathrm{Cl}$. Afterwards, the crude products were purified by column chromatography (silica gel; $\mathrm{Et}_{2} \mathrm{O}$ ) to give the corresponding substituted derivatives 8-12 (Scheme 4) in high yields (Table 2).

\section{Scheme 4. Lithiation and substitution of $N^{\prime}$-(2-(2-methylphenyl)ethyl)- $N, N$-dimethylurea} (4)<smiles>Cc1ccccc1CCNC(=O)N(C)C</smiles>

Table 2. Synthesis of Substituted $N^{\prime}$-(2-(2-Methylphenyl)ethyl)- $N, N$-dimethylureas 7-12 According to Scheme 4 


\begin{tabular}{|c|c|c|c|}
\hline Products & Electrophile & $\mathrm{E}$ & Yield $(\%)^{a}$ \\
\hline 7 & $\mathrm{Ph}_{2} \mathrm{CO}$ & $\mathrm{Ph}_{2} \mathrm{C}(\mathrm{OH})$ & $93^{b}$ \\
\hline 8 & 4- $\mathrm{MeOC}_{6} \mathrm{H}_{4} \mathrm{COMe}$ & $4-\mathrm{MeOC}_{6} \mathrm{H}_{4} \mathrm{C}(\mathrm{OH}) \mathrm{Me}$ & $82^{c}$ \\
\hline 9 & $\left(\mathrm{CH}_{2}\right)_{5} \mathrm{CO}$ & $\left(\mathrm{CH}_{2}\right)_{5} \mathrm{C}(\mathrm{OH})$ & $90^{d}$ \\
\hline 10 & $\mathrm{Me}_{2} \mathrm{NCHO}$ & $\mathrm{CHO}$ & 84 \\
\hline 11 & $\mathrm{PhCHO}$ & $\mathrm{PhCH}(\mathrm{OH})$ & $82^{c}$ \\
\hline 12 & $4-\mathrm{MeOC}_{6} \mathrm{H}_{4} \mathrm{CHO}$ & $4-\mathrm{MeOC}_{6} \mathrm{H}_{4} \mathrm{CH}(\mathrm{OH})$ & $78^{c}$ \\
\hline \multicolumn{4}{|c|}{$\begin{array}{l}{ }^{a} \text { Yield of the pure product. }{ }^{b} \text { The }{ }^{13} \mathrm{C} \text { NMR spectrum showed that the carbons of the two } \\
\text { phenyl groups appeared as separated signals, verifying that they are diastereotopic. }{ }^{c} \text { The NMR } \\
\text { spectra showed a mixture of two racemic diastereoisomers in approximately equal } \\
\text { proportions. }{ }^{d} \text { The }{ }^{13} \mathrm{C} \text { NMR spectrum showed that the two sides of the cyclohexane ring } \\
\text { appeared as separated signals, verifying that they are diastereotopic. }\end{array}$} \\
\hline
\end{tabular}

Clearly, substitution of $\mathbf{4}$ on the $\alpha$-position of the side chain was quite general. The NMR spectra of all compounds showed that the signals of the two hydrogens of the $\mathrm{CH}_{2}$ group were diastereotopic.

It was of interest to know whether lithiation of $N$-(2-(2methylphenyl)ethyl)pivalamide would behave in the same way towards lithiation as the urea derivative. Therefore, $\mathrm{N}$-(2-methylphenethyl)pivalamide (13) was synthesized (in 93\% yield), based on a literature procedure for analogous compounds (Scheme 5). ${ }^{9}$

\section{Scheme 5. Synthesis of $N$-(2-(2-methylphenyl)ethyl)pivalamide (13)}<smiles>Cc1ccccc1CCN</smiles>

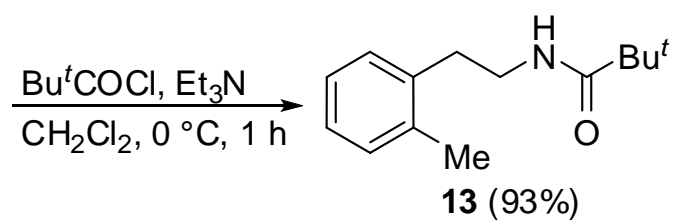

Lithiation of $\mathbf{1 3}$ under the standard conditions that were used for 4 (Scheme 4), followed by reaction with benzophenone as a representative electrophile at $0{ }^{\circ} \mathrm{C}$, gave the corresponding $\alpha$-substituted product $\mathbf{1 4}$ in $86 \%$ yield (Scheme 6). Again no product due to lateral lithiation and substitution was isolated.

Scheme 6. Lithiation of 13 followed by reaction with benzophenone 


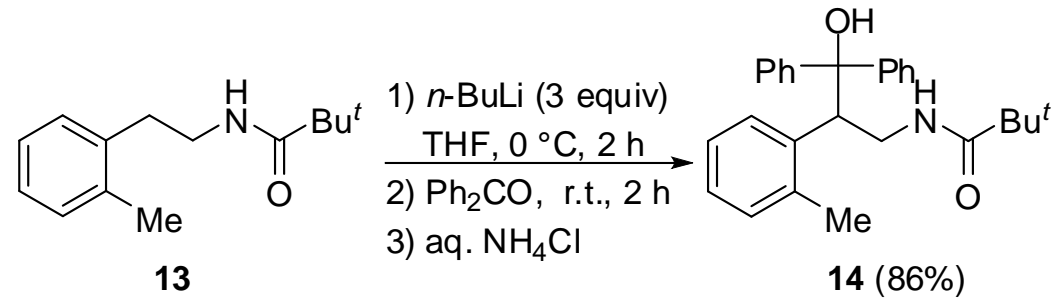

The ${ }^{1} \mathrm{H}$ NMR spectrum of compound $\mathbf{1 4}$ showed that the signals of the two hydrogens of the $\mathrm{CH}_{2}$ group are diastereotopic. Also, its ${ }^{13} \mathrm{C}$ NMR spectrum showed that the carbons of the two phenyl groups appeared as separated signals, verifying that they are diastereotopic.

The high selectivity for $\alpha$-lithiation, with no evidence for lateral lithiation on the methyl group, shown by both $N^{\prime}$-(2-(2-methylphenyl)ethyl)- $N, N$-dimethylurea (4) and $N$-(2-(2-methylphenyl)ethyl)pivalamide (13) were completely at odds with the lateral lithiation of tert-butyl 2-(2-methylphenyl)ethylcarbamate (15) reported by Clark, ${ }^{14}$ albeit that Clark's conditions were somewhat different (lithiation with $t$-BuLi at $-60{ }^{\circ} \mathrm{C}, 1.5 \mathrm{~h}$ ).

Lithiations of $\mathbf{4}$ and $\mathbf{1 3}$ were therefore attempted under Clark's conditions, ${ }^{14}$ followed by reactions with benzophenone in each case. The corresponding $\alpha$-substituted products 7 and 14 were still obtained, in 63 and 52\% yields respectively, along with significant quantities of starting materials. No products due to lateral lithiation and substitution were isolated.

In view of this significant difference, we decided to re-investigate lithiation of $\mathbf{1 5}$, and this compound was therefore synthesized by the literature procedure. ${ }^{15}$ It was obtained in $90 \%$ yield. Lithiation of $\mathbf{1 5}$ under the standard conditions that were used for $\mathbf{4}$ using three equivalents of $n$-BuLi, followed by reaction with benzophenone (1.2 equiv.) as a representative electrophile at $0{ }^{\circ} \mathrm{C}$, gave the corresponding lateral substituted product 16 (Figure 1) as the only observable product, but in low yield (13\%). The yield of $\mathbf{1 6}$ was slightly higher (16\%) when $t$-BuLi (3 equiv.) was used instead of $n$-BuLi, and slightly higher again (20\%) when three equivalents of benzophenone were used with $t$-BuLi. Significant quantities of 15 ( $c a .70-80 \%)$ were recovered under all the above conditions. There was no evidence for the formation of $\alpha$-substitution product in any of the reactions. When the reaction was carried out under Clark's conditions with 1.5 equivalents of benzophenone the yield of $\mathbf{1 6}$ was good $(80 \%)$ and this was improved further to $88 \%$ when excess benzophenone (2.4 equiv.) was used.

Figure 1. Structures of 15-18 
<smiles>CCCCC(=O)NCCc1ccccc1C</smiles>

15<smiles>CCOC(=NCCc1ccccc1CC(O[Ga])(c1ccccc1)c1ccccc1)OC</smiles><smiles>CCCCC(=O)NCCc1ccccc1CC(O)(c1ccccc1)c1ccccc1</smiles><smiles>CCOC(=NCCc1ccccc1C)OC</smiles>

18

There are several possible explanations for the low yields of $16(13-20 \%)$ obtained at higher temperature $\left(0{ }^{\circ} \mathrm{C}\right)$. It is unlikely that lateral lithiation is slow at $0{ }^{\circ} \mathrm{C}$, since lithiation occurs readily enough at -60 to $-25^{\circ} \mathrm{C}$. It was thought to be possible that the dilithium intermediate 17 (Figure 1), produced in-situ from reaction of 18 and benzophenone, may be unstable, dissociating back to benzophenone and lateral-lithiated species $\mathbf{1 8}$ and that the proportion of $\mathbf{1 7}$ in the equilibrium mixture would be lower at higher temperature. This possibility was tested by treating 16 with $t$-BuLi (2.4 equiv.) in dry THF at $0{ }^{\circ} \mathrm{C}$ for $2 \mathrm{~h}$. However, following work up $\mathbf{1 6}$ was recovered quantitatively (98\%). Another possible explanation would be that at $0{ }^{\circ} \mathrm{C}$ the lateral-lithiated species 18 might be reactive enough to deprotonate THF, leading to the mono-lithiated derivative of the starting material $\mathbf{1 5}$, which does not react with benzophenone. A higher yield of $\mathbf{1 6}$ (32\% rather than 20\%) was obtained when the reaction was conducted at $0{ }^{\circ} \mathrm{C}$ in diethyl ether, providing some support for this possibility, but it is likely that there are also other factors in operation.

The clear distinction between the carbamate $\mathbf{1 5}$ on the one hand and the urea $\mathbf{4}$ and pivalamide 13 derivatives of 2-(2-methylphenyl)ethylamine on other hand, with 15 leading to clean lateral lithiation on the methyl group while the other derivatives lead to clean $\alpha$-lithiation on the $\mathrm{CH}_{2}$ group, is surprising. PM3 calculations suggested that for all three compound types the dianions (such as $\mathbf{1 8}$ ) resulting from abstraction of protons from the $\mathrm{NH}$ and methyl positions are intrinsically more stable than the corresponding dianions (such as 6 ) resulting from abstraction of protons from the $\mathrm{NH}$ and $\alpha-\mathrm{CH}_{2}$ positions, by $18-43 \mathrm{~kJ} \mathrm{~mol}^{-1}$ depending on the acyl substituent. Therefore, the intrinsic pKa values of the appropriate protons would be expected to lead to lateral lithiation in all cases. Based on the $\mathrm{C}=\mathrm{O}$ stretching frequencies of the three derivatives, the carbamate would probably be the poorest at coordinating the organolithium reagent and therefore least likely to effect proximity-directed 
lithiation. This would imply that directed lithiation in the case of $\mathbf{4}$ and $\mathbf{1 3}$ favors $\alpha$-lithiation, which would involve a smaller ring-size of interaction between the coordinated organolithium and the $\alpha$-protons than between the coordinated organolithium and the protons of the methyl group. It would further imply that when coordination is insufficiently strong to effect directed lithiation, so that the intrinsic reactivity of the relevant protons becomes the dominant influence over the site of lithiation, a more acidic methyl proton in mono-deprotonated $\mathbf{1 5}$ is the one removed. However, whatever the precise explanation, it is clear that by varying the acyl substituent on nitrogen, it is possible to select either $\alpha$-lithiation or lateral lithiation of a 2-(2-methylphenyl)ethylamine derivative, which must have significant benefit for organic synthesis.

\section{CONCLUSIONS}

Unexpected side-chain lithiation of $N^{\prime}$-(2-(2-methylphenyl)ethyl)- $N, N$-dimethylurea took place at the $\mathrm{CH}_{2}$ group next to the phenyl ring ( $\alpha$-lithiation) with three equivalents of $n$ BuLi in THF at $0{ }^{\circ} \mathrm{C}$. Reactions of the dilithium reagent obtained with a variety of electrophiles gave the corresponding $\alpha$-substituted derivatives in high yields. The process is simple, general, efficient and high yielding to provide a range of substituted urea derivatives that might be difficult to prepare by other means. Similarly, lithiation of $N$-(2-(2-methylphenyl)ethyl)pivalamide followed by reaction with benzophenone as a representative electrophile gave the corresponding $\alpha$-substituted product in high yield. No products due to lateral lithiation and substitution were obtained under the conditions tried, which is in sharp contrast with the results obtained with tert-butyl 2-(2-methylphenyl)ethylcarbamate.

\section{EXPERIMENTAL}

General Experimental Details. Melting point determinations were performed by the open capillary method using a melting point apparatus and are reported uncorrected. ${ }^{1} \mathrm{H}$ and ${ }^{13} \mathrm{C}$ NMR spectra were recorded on a spectrometer operating at $500 \mathrm{MHz}$ for ${ }^{1} \mathrm{H}$ and $125 \mathrm{MHz}$ for ${ }^{13} \mathrm{C}$ measurements. Chemical shifts $\delta$ are reported in parts per million (ppm) relative to TMS and coupling constants $J$ are in $\mathrm{Hz}$, reported to the nearest $0.5 \mathrm{~Hz}$. High-resolution mass spectra were recorded on a time-of-fight mass spectrometer using electron impact (EI). 
$N^{\prime}$-(2-(2-Methylphenyl)ethyl)- $N, N$-dimethylurea (4). A stirred mixture of 3 (9.67 g, $71.6 \mathrm{mmol}$ ), dimethylcarbamoyl chloride (DMCC, $8.68 \mathrm{~g}, 80.7 \mathrm{mmol}$ ) and $\mathrm{Et}_{3} \mathrm{~N}$ (9.97 g, 98.5 mmol) in $\mathrm{CH}_{2} \mathrm{Cl}_{2}(100 \mathrm{~mL})$ was heated under reflux for $1 \mathrm{~h}$. The mixture was allowed to cool and the solid formed was collected by filtration and then washed with $\mathrm{H}_{2} \mathrm{O}(2 \times 25 \mathrm{~mL})$. The solid was purified by crystallization from a mixture of EtOAc and $\mathrm{Et}_{2} \mathrm{O}$ (1:3 by volume) to give pure 4 (14.00 g, 95\%); white solid; mp $74-76{ }^{\circ} \mathrm{C} ;{ }^{1} \mathrm{H}$ NMR $\left(500 \mathrm{MHz}, \mathrm{CDCl}_{3}\right) \delta$ 7.19-7.14 (m, 4H), 4.48 (br, exch., 1H), 3.46 (t, $J=7$ Hz, 2H), 2.88 (s, 6H), 2.86 (t, $J=7 \mathrm{~Hz}$, $2 \mathrm{H}), 2.37$ (s, 3H). ${ }^{13} \mathrm{C}$ NMR (125 MHz, $\left.\mathrm{CDCl}_{3}\right) \delta 158.4,137.5,136.5,130.4,129.4,126.5$, 125.9, 41.0, 36.1, 33.9, 19.3. HRMS calcd for $\mathrm{C}_{12} \mathrm{H}_{18} \mathrm{~N}_{2} \mathrm{O}\left(\mathrm{M}^{+}\right)$206.1419; found 206.1414.

\section{Substituted $\quad N^{\prime}$-(2-(2-Methylphenyl)ethyl)- $N, N$-dimethylureas $\quad 7-12 ; \quad$ General}

Procedure. A solution of $n$-BuLi in hexane $(1.82 \mathrm{~mL}, 1.60 \mathrm{M}, 2.91 \mathrm{mmol})$ was added to a stirred solution of $2(0.20 \mathrm{~g}, 0.97 \mathrm{mmol})$ at $0{ }^{\circ} \mathrm{C}$ in anhydrous THF $(15 \mathrm{~mL})$ under a $\mathrm{N}_{2}$ atmosphere. The mixture was stirred at $0{ }^{\circ} \mathrm{C}$ for $2 \mathrm{~h}$ and the electrophile $(1.16 \mathrm{mmol})$, in anhydrous THF ( $5 \mathrm{~mL}$ ) if solid, neat otherwise, was added. The reaction mixture was stirred for $2 \mathrm{~h}$ at $0{ }^{\circ} \mathrm{C}$. The reaction mixture was quenched with a saturated aqueous solution of $\mathrm{NH}_{4} \mathrm{Cl}(20 \mathrm{~mL})$ and diluted with $\mathrm{Et}_{2} \mathrm{O}(20 \mathrm{~mL})$. The organic layer was separated, washed with $\mathrm{H}_{2} \mathrm{O}(2 \times 20 \mathrm{~mL})$, dried $\left(\mathrm{MgSO}_{4}\right)$ and evaporated under reduced pressure. The residue obtained was purified by column chromatography ( silica gel; $\mathrm{Et}_{2} \mathrm{O}$ ) to give the pure products. The yields obtained of products 7-12 were in the range of 74-93\% based on the starting material 4 (Table 2).

\section{$N^{\prime}$-[3-Hydroxy-2-(2-methylphenyl)-3,3-diphenylpropyl]- $N, N$-dimethylurea}

0.35 g (93\%); white solid; mp 163-166 ${ }^{\circ} \mathrm{C} .{ }^{1} \mathrm{H}$ NMR (500 MHz, $\left.\mathrm{CDCl}_{3}\right) \delta 7.79$ (d, J=8 Hz, $1 \mathrm{H}), 7.70$ (dd, $J=1,8 \mathrm{~Hz}, 2 \mathrm{H}), 7.24$ (apt. t, $J=8 \mathrm{~Hz}, 2 \mathrm{H}$ ), 7.17 (dd, $J=1,8 \mathrm{~Hz}, 2 \mathrm{H}$ ), 7.10 (app. t, $J=8 \mathrm{~Hz}, 1 \mathrm{H}$ ), 6.95 (app. dt, $J=1,8 \mathrm{~Hz}, 1 \mathrm{H}$ ), 6.90-6.86 (m, 4H), 6.79 (app. t, $J=8$ Hz, 1H), 5.53 (br s, exch., 1H), 4.40 (dd, $J=5,8.5 \mathrm{~Hz}, 1 \mathrm{H}), 4.03-3.92(\mathrm{~m}, 2 \mathrm{H}), 3.20(\mathrm{~m}, 1 \mathrm{H})$, $2.43(\mathrm{~s}, 6 \mathrm{H}), 2.22$ (s, 3H). ${ }^{13} \mathrm{C} \mathrm{NMR}\left(125 \mathrm{MHz}, \mathrm{CDCl}_{3}\right) \delta 158.6,148.6,146.7,138.6,135.9$, 129.7, 129.5, 127.9, 127.2, 126.22, 126.20, 125.8, 125.8, 125.6, 125.5, 79.2, 48.0, 42.6, 35.8, 20.2. HRMS calcd for $\mathrm{C}_{25} \mathrm{H}_{26} \mathrm{~N}_{2} \mathrm{O}\left(\mathrm{M}-\mathrm{H}_{2} \mathrm{O}^{+}\right)$370.2045; found 370.2040.

\section{$N^{\prime}$-[3-Hydroxy-2-(2-methylphenyl)-3-(4-methoxyphenyl)butyl]- $N, N$-dimethylurea}

(8). Product $8(0.28 \mathrm{~g}, 82 \%)$ was a mixture of two racemic diastereoisomers in approximately 
equal proportions; yellow oil. ${ }^{1} \mathrm{H}$ NMR $\left(500 \mathrm{MHz}, \mathrm{CDCl}_{3}\right) \delta 7.66(\mathrm{br} \mathrm{d}, J=8 \mathrm{~Hz}, 1 \mathrm{H}), 7.43$ $(\mathrm{d}, J=9 \mathrm{~Hz}, 2 \mathrm{H}), 7.26-6.97(\mathrm{~m}, 11 \mathrm{H}), 6.89(\mathrm{~d}, J=9 \mathrm{~Hz}, 2 \mathrm{H}), 6.78(\mathrm{~d}, J=9 \mathrm{~Hz}, 2 \mathrm{H}), 4.34(\mathrm{br}$ s, exch., 1H), 4.04 (br s, exch., 1H), 3.87 (m, 1H), 3.83 (s, 3H), 3.79 (m, 1H), 3.74 (s, 3H), $3.75(\mathrm{~m}, 1 \mathrm{H}), 3.39-3.29(\mathrm{~m}, 2 \mathrm{H}), 3.20(\mathrm{~m}, 1 \mathrm{H}), 2.79(\mathrm{~s}, 6 \mathrm{H}), 2.57(\mathrm{~s}, 6 \mathrm{H}), 2.39(\mathrm{~s}, 3 \mathrm{H}), 2.28$ $(\mathrm{s}, 3 \mathrm{H}), 1.61(\mathrm{~s}, 3 \mathrm{H}), 1.21(\mathrm{~s}, 3 \mathrm{H}) .{ }^{13} \mathrm{C} \mathrm{NMR}\left(125 \mathrm{MHz}, \mathrm{CDCl}_{3}\right) \delta 158.6,158.5,158.3,158.1$, 141.2 , 139.0, 138.9, 137.5, 137.0, 136.5, 130.4, 130.3, 129.5, 128.3, 127.1, 126.6, 126.7, 126.2, 126.3, 125.8, 113.2, 113.0, 75.6, 74.6, 55.3, 55.2, 49.8, 46.3, 42.1, 41.0, 36.1, 35.8, 30.4, 29.8, 20.4, 19.3. HRMS calcd for $\mathrm{C}_{21} \mathrm{H}_{26} \mathrm{~N}_{2} \mathrm{O}_{2}\left(\mathrm{M}-\mathrm{H}_{2} \mathrm{O}^{+}\right)$338.1994; found 338.1997.

$N^{\prime}$-[2-(1-Hydroxycyclohexyl)-2-(2-methylphenyl)ethyl]- $N, N$-dimethylurea

(9). 0.26 g (90\%); white solid; mp 164-166 ${ }^{\circ} \mathrm{C} .{ }^{1} \mathrm{H}$ NMR $\left(500 \mathrm{MHz}, \mathrm{CDCl}_{3}\right) \delta 7.43(\mathrm{~d}, J=7.5 \mathrm{~Hz}$, 1H), 7.13-7.03 (m, 3H), 4.22 (dd, $J=5,6 \mathrm{~Hz}$, exch., 1H), $3.87(\mathrm{~m}, 1 \mathrm{H}), 3.35(\mathrm{~m}, 1 \mathrm{H}), 3.15$ $(\mathrm{m}, 1 \mathrm{H}), 2.63(\mathrm{~s}, 6 \mathrm{H}) 2.23(\mathrm{~s}, 3 \mathrm{H}), 1.57-1.01(\mathrm{~m}, 10 \mathrm{H}) .{ }^{13} \mathrm{C} \mathrm{NMR}\left(125 \mathrm{MHz}, \mathrm{CDCl}_{3}\right) \delta 158.7$, 138.9, 137.9, 130.4, 128.0, 126.3, 126.0, 73.5, 49.7, 41.4, 36.3, 35.5, 35.9, 25.7, 21.8, 21.6), 20.6. HRMS calcd for $\mathrm{C}_{18} \mathrm{H}_{28} \mathrm{~N}_{2} \mathrm{O}_{2}\left(\mathrm{M}^{+}\right)$304.2151; found 304.2145.

$N^{\prime}$-[3-Oxo-2-(2-methylphenyl)propyl]- $N, N$-dimethylurea $\quad(10) . \quad 0.23 \quad \mathrm{~g} \quad(84 \%)$; yellow oil. ${ }^{1} \mathrm{H}$ NMR $\left(500 \mathrm{MHz}, \mathrm{CDCl}_{3}\right) \delta 9.64$ (br, $\left.1 \mathrm{H}\right), 7.20-7.04(\mathrm{~m}, 3 \mathrm{H}), 6.83(\mathrm{dd}, J=1,7$ Hz, 1H), 4.91 (app. t, $J=5 \mathrm{~Hz}$, exch., 1H), 4.15 (dd, $J=5,9 \mathrm{~Hz}, 1 \mathrm{H}), 3.54$ (m, 1H), 3.45 (m, 1H), 2.79 (s, 6H), 2.41 (s, 3H). $\left.{ }^{13} \mathrm{C} \mathrm{NMR} \mathrm{(125} \mathrm{MHz,} \mathrm{CDCl}_{3}\right) \delta 201.4,158.2,137.8,132.4$, 131.3, 128.0, 126.5, 55.7, 41.1, 36.1, 19.6. HRMS calcd for $\mathrm{C}_{13} \mathrm{H}_{18} \mathrm{~N}_{2} \mathrm{O}_{2}\left(\mathrm{M}^{+}\right)$234.1368; found 234.1372 .

\section{$N^{\prime}$-[3-(Hydroxy)-3-(phenyl)-2-(2-methylphenyl)propyl]- $N, N$-dimethylurea}

(11).

Product $11(0.24 \mathrm{~g}, 82 \%)$ was a mixture of two racemic diastereoisomers in approximately equal proportions; yellow oil. ${ }^{1} \mathrm{H}$ NMR $\left(500 \mathrm{MHz}, \mathrm{CDCl}_{3}\right) \delta 7.28-6.92(\mathrm{~m}, 18 \mathrm{H}), 4.94$ (br s, exch., 2H), 4.90 (d, $J=5.5 \mathrm{~Hz}, 1 \mathrm{H}), 4.82$ (d, $J=5.5 \mathrm{~Hz}, 1 \mathrm{H}$ ), 4.58 (app. t, $J=5.5 \mathrm{~Hz}$, exch., 1H), 4.38 (app. t, $J=5.5 \mathrm{~Hz}$, exch., 1H), 3.93 (m, 1H), 3.57 (m, 1H), 3.37-3.30 (m, 4H), 2.77 $(\mathrm{s}, 6 \mathrm{H}), 2.70(\mathrm{~s}, 6 \mathrm{H}), 1.99(\mathrm{~s}, 3 \mathrm{H}) .1 .96(\mathrm{~s}, 3 \mathrm{H}) .{ }^{13} \mathrm{C} \mathrm{NMR}\left(125 \mathrm{MHz}, \mathrm{CDCl}_{3}\right) \delta$ 159.18, $159.15,142.96,142.94,139.12$, 139.11, 136.31, 136.30, 130.54, 153.53, 127.98, 127.82, 127.35 , 127.34, 127.03, 127.00, 126.6, 126.5, 126.35, 126.34, 125.73, 125.72, 75.1, 74.6, 49.4, 48.8, 43.0, 42.3, 36.2, 36.1, 19.72, 19.70. HRMS calcd for $\mathrm{C}_{19} \mathrm{H}_{23} \mathrm{~N}_{2} \mathrm{O}\left(\mathrm{M}-\mathrm{OH}^{+}\right)$ 295.1810; found 295.1798. 


\section{$N^{\prime}$-[3-(Hydroxy)-3-(4-methoxyphenyl)-2-(2-methylphenyl)propyl]- $N, N$ -}

dimethylurea (12). Product $12(0.26 \mathrm{~g}, 78 \%)$ was a mixture of two racemic diastereoisomers in approximately equal proportions; yellow oil. ${ }^{1} \mathrm{H} \mathrm{NMR}\left(500 \mathrm{MHz}, \mathrm{CDCl}_{3}\right) \delta 7.41$ (br d, $J=$ $8 \mathrm{~Hz}, 2 \mathrm{H}), 7.32$ (d, $J=9 \mathrm{~Hz}, 2 \mathrm{H}), 7.13$ (br t, $J=8 \mathrm{~Hz}, 2 \mathrm{H}), 7.06-6.98$ (m, 6H), 6.83 (d, $J=9$ Hz, 2H), 6.69 (d, $J=9 \mathrm{~Hz}, 2 \mathrm{H}), 4.84$ (d, $J=6 \mathrm{~Hz}, 2 \mathrm{H}$ ), 4.30 (app. t, $J=5.5 \mathrm{~Hz}$, exch., 2H) $3.68(\mathrm{~s}, 6 \mathrm{H}), 3.32-3.28(\mathrm{~m}, 4 \mathrm{H}), 3.17-3.12$ (m, 2H), 2.98 (br s, 2H), 2.70 (s, 12H), 1.98 (s, $6 \mathrm{H}) .{ }^{13} \mathrm{C}$ NMR $\left(125 \mathrm{MHz}, \mathrm{CDCl}_{3}\right) \delta 158.98,158.95,158.83,158.81,137.7,137.6,134.5$, 134.4), 132.5, 132.4, 130.25, 130.21, 129.12, 129.09, 127.77, 127.74, 126.64, 126.61, 126.12, 126.09, 113.57, 113.51, 74.87, 74.85, 55.3, 55.2, 48.55, 48.52, 43.12, 43.14, 36.12, 36.10, 19.9, 19.8. HRMS calcd for $\mathrm{C}_{20} \mathrm{H}_{25} \mathrm{~N}_{2} \mathrm{O}_{2}\left(\mathrm{M}-\mathrm{OH}^{+}\right) 325.1916$; found 325.1912.

$N$-(2-(2-Methylphenyl)ethyl)pivalamide (13). To a cooled solution $\left(0{ }^{\circ} \mathrm{C}\right)$ of $\mathbf{3}(6.50$ g, $48.1 \mathrm{mmol})$ and $\mathrm{Et}_{3} \mathrm{~N}(12.0 \mathrm{~mL})$ in $\mathrm{CH}_{2} \mathrm{Cl}_{2}(50 \mathrm{~mL})$ pivaloyl chloride $(6.42 \mathrm{~g}, 53.3 \mathrm{mmol})$ was slowly added in a dropwise manner over $30 \mathrm{~min}$. The reaction mixture was stirred at room temperature for $1 \mathrm{~h}$. The mixture was poured onto $\mathrm{H}_{2} \mathrm{O}(50 \mathrm{~mL})$ and the organic layer was separated, washed with $\mathrm{H}_{2} \mathrm{O}(2 \times 50 \mathrm{~mL})$ and dried $\left(\mathrm{MgSO}_{4}\right)$ and the solvent was then removed under reduced pressure. The solid obtained was purified by crystallization from $\mathrm{Et}_{2} \mathrm{O}$-hexane (1:1 by volume) to give pure 13 (9.81 g, 93\%). white solid; mp $85-88{ }^{\circ} \mathrm{C} .{ }^{1} \mathrm{H}$ NMR (500 MHz, $\mathrm{CDCl}_{3}$ ) $\delta$ 7.20-7.12 (m, 4H), 5.69 (br s, exch., 1H), 3.49 (app. q, $J=7 \mathrm{~Hz}$, $2 \mathrm{H}), 2.85(\mathrm{t}, J=7 \mathrm{~Hz}, 2 \mathrm{H}), 2.38(\mathrm{~s}, 3 \mathrm{H}), 1.18(\mathrm{~s}, 9 \mathrm{H}) .{ }^{13} \mathrm{C} \mathrm{NMR}\left(125 \mathrm{MHz}, \mathrm{CDCl}_{3}\right) \delta 178.3$, $137.0,136.4,130.5,129.4,126.6,126.0,39.4,38.7,33.1,27.5,19.3$. HRMS calcd for $\mathrm{C}_{14} \mathrm{H}_{21} \mathrm{NO}\left(\mathrm{M}^{+}\right)$219.1623; found 219.1623.

$N$-[3-Hydroxy-3,3-diphenyl-2-(2-methylphenyl)propyl]pivalamide (14). The procedure was identical with that described for lithiation and substitution of $\mathbf{4}$ except that it involved $13(0.20 \mathrm{~g}, 0.91 \mathrm{mmol})$, with benzophenone $(0.20 \mathrm{~g}, 1.09 \mathrm{mmol})$ as the electrophile, and was carried out at $0{ }^{\circ} \mathrm{C}$. Following work-up the crude product was purified by column chromatography (silica gel; $\left.\mathrm{Et}_{2} \mathrm{O}\right)$ to give pure 14 (0.31 g, 86\%); white solid; mp 95-98 ${ }^{\circ} \mathrm{C}$. ${ }^{1} \mathrm{H}$ NMR (500 MHz, $\left.\mathrm{CDCl}_{3}\right) \delta 7.63(\mathrm{dd}, J=1,7.5 \mathrm{~Hz}, 2 \mathrm{H}), 7.58(\mathrm{~d}, J=8 \mathrm{~Hz}, 1 \mathrm{H}), 7.26$ (app. t, $J=7.5 \mathrm{~Hz}, 2 \mathrm{H}), 7.13-7.09(\mathrm{~m}, 1 \mathrm{H}), 6.99(\mathrm{dd}, J=1,7.5 \mathrm{~Hz}, 2 \mathrm{H}), 6.96(\mathrm{t}, J=7.5 \mathrm{~Hz}, 1 \mathrm{H})$, 6.86 (app. t, $J=7.5 \mathrm{~Hz}, 2 \mathrm{H}), 6.89-6.80$ (m, 3H), 5.32 (t, $J=6 \mathrm{~Hz}$, exch., $1 \mathrm{H}$ ), 4.37 (app. t, $J=$ $7 \mathrm{~Hz}, 1 \mathrm{H}), 3.94$ (br s, exch., 1H), 3.83 (m, 1H), 3.26 (m, 1H), 1.97 (s, 3H), 0.78 (s, 9H). ${ }^{13} \mathrm{C}$ NMR $\left(125 \mathrm{MHz}, \mathrm{CDCl}_{3}\right) \delta 179.4,146.8,146.3,137.6,137.1,130.0,129.1,128.3,127.3$, 
126.9, 126.4, 126.3, 126.0, 125.9, 125.7, 79.8, 46.3, 41.2, 38.4, 27.2, 20.0. HRMS calcd for $\mathrm{C}_{27} \mathrm{H}_{29} \mathrm{NO}\left(\mathrm{M}-\mathrm{H}_{2} \mathrm{O}^{+}\right)$383.2253; found 383.2249.

tert-Butyl 2-(2-methylphenyl)ethylcarbamate (15). Compound 15 was prepared based on a modified literature procedure. ${ }^{15}$ However, the literature procedure was reported to give an oil and its ${ }^{1} \mathrm{H}$ NMR spectral data appeared to be wrong. No ${ }^{13} \mathrm{C}$ NMR spectral data were reported, and moreover, the purity was less than $93 \%$ and no yield was reported. ${ }^{15}$

To a cooled solution $\left({ }^{\circ} \mathrm{C}\right)$ of $3(2.00 \mathrm{~g}, 14.8 \mathrm{mmol})$ and $\mathrm{Et}_{3} \mathrm{~N}(2.85 \mathrm{~mL})$ in $\mathrm{CH}_{2} \mathrm{Cl}_{2}$ $(20 \mathrm{~mL})$ di-tert-butyl dicarbonate $(4.20 \mathrm{~g}, 19.2 \mathrm{mmol})$ was slowly added in a dropwise manner. The cooling bath was removed and the reaction mixture was stirred under reflux for 1 h. The mixture was allowed to cool to room temperature and poured onto $\mathrm{H}_{2} \mathrm{O}(50 \mathrm{~mL})$. The organic layer was separated, washed with $\mathrm{H}_{2} \mathrm{O}(2 \times 50 \mathrm{~mL})$ and dried $\left(\mathrm{MgSO}_{4}\right)$ and the solvent was then removed under reduced pressure. The solid obtained was purified by crystallization from hexane to give 15 (3.13 g, 90\%); white solid; mp $56-59{ }^{\circ} \mathrm{C}$ (Lit. ${ }^{15}$ oil). ${ }^{1} \mathrm{H}$ NMR (500 MHz, $\left.\mathrm{CDCl}_{3}\right) \delta 7.08-7.04$ (m, 4H), 4.51 (br s, exch., 1H), 3.26 (t, $\left.J=7 \mathrm{~Hz}, 2 \mathrm{H}\right)$, $2.73(\mathrm{t}, J=7 \mathrm{~Hz}, 2 \mathrm{H}), 2.26(\mathrm{~s}, 3 \mathrm{H}), 1.37(\mathrm{~s}, 9 \mathrm{H}) .{ }^{13} \mathrm{C} \mathrm{NMR}\left(125 \mathrm{MHz}, \mathrm{CDCl}_{3}\right) \delta 155.9,137.1$, $136.4,130.4,129.4,126.5,126.0,79.2,40.7,33.6,28.4$, 19.3. HRMS calcd for $\mathrm{C}_{14} \mathrm{H}_{21} \mathrm{NO}_{2}$ $\left(\mathrm{M}^{+}\right)$235.1572; found 235.1572.

tert-Butyl 2-(2-(2-hydroxy-2,2-diphenylethyl)phenyl)ethylcarbamate (16). A solution of $t$-BuLi in hexane $(1.07 \mathrm{~mL}, 1.90 \mathrm{M}, 2.04 \mathrm{mmol})$ was added to a stirred solution of 15 (0.20 g, $0.85 \mathrm{mmol})$ at $-60{ }^{\circ} \mathrm{C}$ in anhydrous THF $(15 \mathrm{~mL})$ under a $\mathrm{N}_{2}$ atmosphere. The mixture was stirred at $c a .-30$ to $-25^{\circ} \mathrm{C}$ for $1.5 \mathrm{~h}$. A solution of benzophenone $(0.37 \mathrm{~g}, 2.04$ mmol) in anhydrous THF $(5 \mathrm{~mL})$ was added at $-60{ }^{\circ} \mathrm{C}$ and the reaction mixture was allowed to warm up to $0{ }^{\circ} \mathrm{C}$ and stirred for $2 \mathrm{~h}$. The reaction mixture was quenched with a saturated aqueous solution of $\mathrm{NH}_{4} \mathrm{Cl}(20 \mathrm{~mL})$ and diluted with $\mathrm{Et}_{2} \mathrm{O}(20 \mathrm{~mL})$. The organic layer was separated, washed with $\mathrm{H}_{2} \mathrm{O}(2 \times 20 \mathrm{~mL})$, dried $\left(\mathrm{MgSO}_{4}\right)$ and evaporated under reduced pressure. The crude product was purified by column chromatography (silica gel; $\mathrm{Et}_{2} \mathrm{O}$ ) to give pure 16 (0.31 g, 88\%); colorless oil. ${ }^{1} \mathrm{H}$ NMR (500 MHz, $\left.\mathrm{CDCl}_{3}\right) \delta 7.31(\mathrm{~d}, J=8 \mathrm{~Hz}, 4 \mathrm{H})$, 7.18 (app. t, $J=8 \mathrm{~Hz}, 4 \mathrm{H}$ ), 7.12 (app. t, $J=8 \mathrm{~Hz}, 2 \mathrm{H}$ ), $7.03-6.99$ (m, 2H), 6.82 (app. dt, $J=$ 2, $8 \mathrm{~Hz}, 1 \mathrm{H}$ ), 6.54 (d, $J=8 \mathrm{~Hz}, 1 \mathrm{H}), 4.56$ (br s, exch., 1H), 4.27 (br, exch., 1H), 3.62 (s, 2H), $3.16(\mathrm{br}, 2 \mathrm{H}), 2.55(\mathrm{t}, J=7 \mathrm{~Hz}, 2 \mathrm{H}), 1.30(\mathrm{~s}, 9 \mathrm{H}) .{ }^{13} \mathrm{C} \mathrm{NMR}\left(125 \mathrm{MHz}, \mathrm{CDCl}_{3}\right) \delta 156.1$, 
147.1, 139.1, 134.5, 131.9, 129.5, 128.7, 128.0, 126.9, 126.5), 125.7, 79.3, 77.3, 43.7, 41.4, 33.0, 28.4. HRMS calcd for $\mathrm{C}_{27} \mathrm{H}_{29} \mathrm{NO}_{2}\left(\mathrm{M}-\mathrm{H}_{2} \mathrm{O}^{+}\right)$399.2198; found 399.2210.

\section{ACKNOWLEDGMENTS}

We thank Cardiff University and the Saudi Government for financial support. We are grateful to Dr. M. C. Elliott and Mr. B. Saleh for carrying out PM3 calculations.

\section{SUPPORTING INFORMATION}

The full characterization and NMR spectra for all products are available. This material is available free of charge via the Internet at http://pubs.acs.org.

\section{REFERENCES}

(1) See for example: (a) Clayden, J. Organolithiums: Selectivity for Synthesis, Pergamon: Oxford, 2002. (b) Schlosser, M. Organometallics in Synthesis, 2nd ed.; Wiley: Chichester, 2002; pp. 1-352. (c) Capriati, V.; Florio, S.; Salomone, A. Topics in Stereochemistry. 2010, 26, 135. (d) Coldham, I.; Sheikh, N. S. Topics in Stereochemistry. 2010, 26, 253.

(2) See for example: (a) Beak, P.; Snieckus, V. Acc. Chem. Res. 1982, 15, 306. (b) Stefinovic, M.; Snieckus, V. J. Org. Chem. 1998, 63, 2808. (c) Green, L.; Chauder, B.; Snieckus, V. J. Heterocycl. Chem. 1999, 36, 1453. (d) Whisler, M. C.; MacNeil, S.; Snieckus, V.; Beak, P. Angew. Chem. Int. Ed. 2004, 43, 2206. (e) Dyke, A. M.; Gill, D. M.; Harvey, J. N.; Hester, A. J.; Lloyd-Jones, G. C.; Muñoz, M. P.; Shepperson I. R. Angew. Chem. Int. Ed. 2008, 47, 5067. (f) Coldham, I.; Raimbault, S.; Chovatia, P. T.; Patel, J. J.; Leonori, D.; Sheikh, N. S.; Whittaker, D. T. E. Chem. Commun. 2008, 4174. (g) Coldham, I.; Leonori, D.; Beng, T. K.; Gawley, R. E. Chem. Commun. 2009, 5239. (h) Coldham, I.; Raimbault, S.; Whittaker, D. T. E.; Chovatia, P. T.; Leonori, D.; Patel, J. J.; Sheikh, N. S. Chem.-A Eur. J. 2010, 16, 4082. (i) Robinson, S. P.; Sheikh, N. S.; Baxter, Carl A.; Coldham, I. Tetrahedron Lett. 2010, 51, 3642. (j) Guerrand, H. D. S.; Adams, H.; Coldham, I. Org. Biomol. Chem. 2011, 9, 7921. (k) Thompson, M. J.; Louth, J. C.; Little, S. M.; Jackson, M. P.; Boursereau, Y.; Chen, B.; Coldham, I. ChemMedChem 2012, 7, 578. (1) Sheikh, N. S.; Leonori, D.; Barker, G.; Firth, J. D.; Campos, K. R.; Meijer, A. J. H. M.; O’Brien, P.; Coldham, I. J. Am. Chem. Soc. 2012, 134, 5300.

(3) See for example: (a) Beak, P.; Zajdel, W. J.; Reitz, D. B. Chem. Rev. 1984, 84, 471. (b) Snieckus, V. Chem. Rev. 1990, 90, 879. (c) Anctil, E. J.-G.; Snieckus, V. J. Organomet. 
Chem. 2002, 653, 150. (d) Smith, K.; El-Hiti, G. A. Curr. Org. Synth. 2004, 1, 253. (e) Schlosser, M. Angew. Chem. Int. Ed. 2005, 44, 376. (f) Foubelo, F.; Yus, M. Curr. Org. Chem. 2005, 9, 459. (g) Florio, S.; Aggarwal, V.; Salomone, A. Org. Lett. 2004, 6, 4191. (h) Capriati, V.; Florio, S.; Luisi, R. Chem. Rev. 2008, 108, 1918. (i) Houlden, C. E.; LloydJones, G. C.; Booker-Milburn, K. I. Org. Lett. 2010, 12, 3090. (j) Page, A.; Clayden, J. Beilstein J. Org. Chem. 2011, 7, 1327.

(4) See for example: (a) Clayden, J.; Turner, H.; Pickworth, M.; Adler, T. Org. Lett. 2005, 7, 3147. (b) Tilly, D.; Fu, J.-M.; Zhao, B.-P.; Alessi, M.; Castanet, A.-S.; Snieckus, V.; Mortier, J. Org. Lett. 2010, 12, 68. (c) Schmid, M.; Waldner, B.; Schnürch, M.; Mihovilovic, M. D.; Stanetty, P. Tetrahedron 2011, 67, 2895. (d) Volz, N.; Clayden, J. Angew. Chem. Int. Ed. 2011, 50, 12148.

(5) See for example: (a) Clark, R. D.; Jahangir; Langston, J. A. Can. J. Chem. 1994, 72, 23. (b) Clark, R. D.; Jahangir, A. Org. React. 1995, 47, 1-314. (c) Smith, K.; El-Hiti, G. A.; Abdel-Megeed, M. F.; Abdo, M. A. J. Org. Chem. 1996, 61, 656. (d) Clayden, J.; Pink, J. H. Tetrahedron Lett. 1997, 38, 2561. (e) Derdau, V.; Snieckus, V. J. Org. Chem. 2001, 66, 1992. (f) Clayden, J.; Stimson, C. C.; Keenan, M.; Wheatley, A. E. H. Chem. Commun. 2004, 228. (g) Clayden, J.; Dufour, J. Tetrahedron Lett. 2006, 47, 6945. (h) Clayden, J.; Dufour, J.; Grainger, D. M.; Helliwell, M. J. Am. Chem. Soc. 2007, 129, 7488. (i) Burgos, P. O.; Fernández, I.; Iglesias, M. J.; García-Granda, S.; Ortiz, F. L. Org. Lett. 2008, 10, 537.

(6) See for example: (a) Smith, K.; El-Hiti, G. A.; Abdel-Megeed, M. F.; Abdo, M. A. J. Org. Chem. 1996, 61, 647. (b) Smith, K.; Barratt, M. L. J. Org. Chem. 2007, 72, 1031.

(7) Smith, K., El-Hiti, G. A., Shukla, A. P. J. Chem. Soc., Perkin Trans. 1 1999, 2305.

(8) Smith, K.; El-Hiti, G. A.; Hegazy, A. S.; Fekri, A.; Kariuki, B. M. ARKIVOC 2009, (xiv), 266.

(9) Smith, K.; El-Hiti, G. A.; Hegazy, A. S. Synthesis 2010, 1371.

(10) Smith, K.; El-Hiti, G. A.; Pritchard, G. J.; Hamilton, A. J. Chem. Soc., Perkin Trans. 1 1999, 2299.

(11) Smith, K.; El-Hiti, G. A.; Hawes, A. C. Synthesis 2003, 2047.

(12) Smith, K.; El-Hiti, G. A.; Hegazy, A. S. Chem. Commun. 2010, 46, 2790.

(13) Smith, K.; El-Hiti, G. A.; Alshammari, M. B. Synthesis 2012, 44, 2013.

(14) Clark, R. D.; Jahangir Tetrahedron 1993, 49, 1351.

(15) Leftheris, K.; Ahmed, G.; Chan, R.; Dyckman, A. J.; Hussain, Z.; Ho, K.; Hynes, J.; Letourneau, J.; Li, W.; Lin, S.; Metzger, A.; Moriarty, K. J.; Riviello, C.; Shimshock, Y.; Wen, J.; Wityak, J.; Wrobleski, S. T.; Wu, H.; Wu, J.; Desai, M.; Gillooly, K. M.; Lin, T. H.; 
Loo, D.; McIntyre, K. W.; Pitt, S.; Shen, D. R.; Shuster, D. J.; Zhang, R.; Diller, D.; Doweyko, A.; Sack, J.; Baldwin, J.; Barrish, J.; Dodd, J.; Henderson, I.; Kanner, S.; Schieven, G. L.; Webb, M. J. Med. Chem. 2004, 47, 6283. 